people". The proposal has been cordially received in Ireland, and now has the official approval of the President of the Irish Free State. The archæological section of the expedition is already at work and during the past summer, under the leadership of Dr. O'Neil Hencken and under the auspices of the National Museum of Ireland, has been engaged in the excavation of a Viking age crannog at Ballinderry, Co. Westmeath, and of bronze age burials nearby at Knockast, with remarkable results. For the study of social anthropology, Co. Clare has been chosen as the area affording most typically a blend of the old and the new in Irish culture. A preliminary survey has been made by Prof. W. Lloyd Warner, assistant professor of social anthropology in Harvard University, assisted by Mr. Conrad Arensburg, postgraduate anthropological student of the University. It is intended to devote two years with an extended staff to the observation of every aspect of Irish social life. Physical anthropology will be under the charge of Prof. E. A. Hooton, of Harvard University, who will also be responsible for the general oversight of the work of the expedition.

\section{Excavation in Alaska}

DuRING the past summer an expedition of the University Museum of Pennsylvania, conducted by Miss Frederika de Laguna, has been at work on the coasts of Alaska in conformity with the policy of American anthropology for the intensive study of this area in relation to the problem of the early peopling of America. The expedition was engaged in the excavation of a prehistoric village site in Kachemak Bay, Cook Inlet. Of the finds of the season, Science Service (Washington D.C.) reports that Miss de Laguna regards the outstanding object to be a carved stone lamp. In the bowl of the lamp is a human figure in an attitude of prayer carved in full relief. Four other examples of such lamps are known; but this is the only example to be found by a scientific explorer in situ. It is said to come from the last phase of four prehistoric Eskimo settlements; but although the early phase of the 'archaic' culture of the area is remarkable for its carved ivories, stone carving is not known as an Eskimo technique. The lamp was found in a shell-heap close to the sea, which is washed by high tide. Other cultural features of the same settlement were slate mirrors, slate blades for lances, bone harpoons and dart heads, grinding stones, awls, drills, dolls, beads and needles. Rock-paintings were found in caves. Such paintings are known only in southern Cook Inlet and on Kodiak Island, where the culture is similar. The Indians of to-day believe that these pictures were painted by 'whale killers', much feared medicinemen who poisoned their lances with human fat. If there were any foundation for this belief, it might be related to the traces of cannibalism found in prehistoric settlements by the Smithsonian Alaskan expeditions.

\section{Spelling of Place Names}

The United States Geographic Board has published a "First Report on Foreign Geographical
Names" (Washington Government Printing Office, 1932. 10 cents). The list of names is prefaced by a long discussion of the problems involved, which is followed by certain general rules that the Board has adopted. The conventional English usage is adopted for the names of countries, dominions, colonies, etc., and for geographical features common to several States in which the official languages are different. For local geographical names in States where a Latin alphabet is used, the names are spelled in accordance with local usage but conventional English forms, where such exist, are accepted as alternatives. Names in non-Latin alphabets are to be transliterated according to either official transliteration, where such exists, or a system adopted by the Board and printed in this report. The practice of translating names is discouraged. The policy adopted by the Board differs little from that used by the Permanent Committee on Geographical Names for British Official Use. The differences lie in the spelling of names in possessions of European powers and in the transliteration of ' $\mathrm{j}$ ' and ' $\mathrm{zh}$ ' in certain languages, but it is laid down that in the absence of any specific decision of the United States Board, the decision of the British Committee is to be followed in certain cases. The actual list of names in the Report gives pronunciation in many cases but omits it in several names where its addition would certainly be useful.

\section{Forest Fires in Japan}

A PAPER on "Forest Fires and Weather" (Sci. Papers Inst. Phys. Chem. Res., Tokyo, vol. 18), by T. Terada and T. Utigasaki, states that the annual loss due to forest fires in Japan is second in magnitude only to that suffered by the United States. Japanese meteorologists might therefore do good service by studying the weather conditions that precede these fires in Japan, and perhaps eventually organising a system of warnings, following the example of the United States. The authors of this paper were led to study this subject with the aid of synoptic weather charts through the known tendency for the fires to break out practically simultaneously in widely scattered parts of Japan. They conclude that such outbreaks are generally associated with the near approach of the 'squall-line' or principal cold front of a depression following an easterly track north of Japan, when the warmer of the two wind currents yields maximum temperatures of $20^{\circ} \mathrm{C}$. or more. There seems no a priori reason why the front should have anything to do with the matter; it is easy to imagine that the necessary antecedent conditions are merely a sufficiency of wind and warmth, with no rain and perhaps some special state of the air in regard to its water-vapour content. These conditions might seldom occur except on the approach of a depression. As frequently happens with investigations in which synoptic charts are used, the extent to which the evidence supports the conclusions cannot be gauged accurately unless all the charts are reproduced in great detail. It must have been difficult for the authors to determine the position of the front in 